\title{
DEVELOPMENT OF YOGHURT-BASED WEANING FOODS FOR 1-3 YEARS OLD TODDLERS BY INCORPORATION OF MUNG BEAN (Vigna radiata), SOYBEAN (Glycine max) AND BROWN RICE (Oryza sativa) FOR THE SRI LANKAN MARKET
}

\author{
M. A. D. D. Munasinghe ${ }^{1}$, K. F. S. T. Silva ${ }^{1}$, K. Jayarathne ${ }^{2}$ and K. H. Sarananda ${ }^{3}$
}

ABSTRACT

Three extruded yoghurt-based weaning foods were formulated at different ratios by blending of brown rice: Rathu kekulu (Oryza sativa), soybean (Glycine max), mung bean (Vigna radiata) and milk powder which blend with yoghurt to achieve the recommended level of nutrients for a toddler aged between 1-3 years. These three formulated products were compared with a commercially available weaning food, Cerelac. Protein, fat, energy, dry matter, ash and water solubility index of formulated weaning foods were significantly $(P<0.05)$ higher than that of the commercial weaning food. Moisture, carbohydrate and water binding capacity were significantly $(P<0.05)$ lower than that of the commercial weaning food. The microbial counts of both flour and yoghurt separately, and for the gruel form were within the limits of recommendations. Moisture content data showed that flour mixtures were stable more than 21 days. Titratable acidity and $\mathrm{pH}$ indicated that the yoghurt was stable untill 6 days. Overall chemical evaluation results suggested the weaning food-2 (Rice-2\%, mung bean-17\%, soybean-3\%, milk-3\%, yoghurt-75\%) as the best weaning food among the yoghurt-based weaning foods evaluated. Results concluded that formulation of the yoghurt-based weaning foods is a good approach to alleviate the malnurishment associated with conventional stipulated cereal-beased weaning floor mixtures given in liquid-gruel form.

Key words: extrusion, yoghurt-based, toddler, weaning food

\section{INTRODUCTION}

Malnutrition has become one of the major health problems facing by developing countries. It has been reported that about 870 million people in the world are undernourished in terms of dietary energy supply in 2012. Out of the total 870 million, 563 million undernourished people are found from Asia which accounts for $13.9 \%$ in the Asian population. Nevertheless, 304 million people in the South Asia are malnourished which provides the highest contribution to the total malnurishment in the world. It is estimated that about $17.6 \%$ from the South Asian population is undernourished (FAO, 2012). Malnutrition in Sri Lanka continues to prevail relatively at higher levels. Sri Lanka Demographic and Health Survey (2006-2007) highlighted that $18 \%, 15 \%, 22 \%$ and $4 \%$ of Sri Lankan children are stunted, wasted, underweighted and severely underweighted, respectively (Department of Census and Statistics, 2009). Malnutrition can be defined as inadequate or excess intake of macro and micro nutrients. Protein Energy Malnutrition (PEM) occurs during the transitional phase when children are weaned from liquid to semi-solid or fully

\footnotetext{
Department of Animal Science, Faculty of Agriculture, University of Peradeniya, Peradeniya, Sri Lanka. 43

MILCO (Pvt) Ltd, Narahenpita, Colombo, Sri Lanka.

3 Food Research Laboratory, HORDI, Department of Agriculture, Gannoruwa, Sri Lanka.
} 
adult foods. High price of commercially available weaning foods, vegetables, animal proteins and the non-availability of low priced nutritious foods, combined with bad feeding practices and late introduction of supplementary foods, are mostly responsible for this malnourishment among children (Suite, 2007).

Moreover, iron deficiency is the most common and widespread micronutrient disorder worldwide which affected over 2 billion people or about $30 \%$ of the world population (WHO, 2013). Asia has the highest prevalence of anemia, the most serious form of iron deficiency which estimated as 182 million where the highest prevalence observed among the pre-school children and nonpregnant women at reproductive stage (WHO, 2008). In developing countries, most of the complementary foods are based on local staple foods mainly produced from cereals and given in liquid gruel form for infants (Sanni et al., 1999; Egounlety, 2002; Obatolu, 2002). To be suitable for the feeding of young children, these cereal-based weaning foods are prepared in liquid form by dilution with a large quantity of water, thereby resulting in more volume but with a low energy and low nutrient dense food (Sanni et al., 1999). These cereal-based gruel forms are poor in nutritional value as they are lack in essential amino acids such as threonine, lysine and tryptophan (Egounlety, 2002). Moreover, the poor quality of protein and high viscosity of such gruel makes it difficult for the child to consume enough to meet both energy and protein requirements and leads to occurrence of protein-energy malnutrition (Egounlety, 2002; Obatolu, 2002).

Good nutrition during infancy and childhood are essential for physical and mental development. Several strategies have been used to improve the nutritive value of weaning foods namely, malting, dry roasting, milling, steaming, boiling, and sprouting which are some simple processes being used in the production of weaning foods (Harper and Jansen, 1985; Wikramanayaka, 1996). Food based approaches used in combination with nutritional education programs can be used as a strategy to overcome the nutrient deficiencies. One such strategy is to incorporate legumes with cereals. Therefore, locally available legumes such as mung bean (Vigna radiata) and soy bean (Glycine max) can be used due to their high protein and iron content. Moreover, these two legumes have been popularized in the South Asian diets since from a long period of time. As these cereals are relatively low cost source of iron and protein, they can be used to prepare supplementary foods for children in low income families (Vijayalakshmi et al., 2003). Legumes are rich in lysine but deficient in sulfur-containing amino acids. On the other hand, cereals are deficient in lysine but rich in sulfur-containing amino acids. Hence, fortification of legumes with cereals is advantageous since blending of these results beneficial nutritional characteristics. On the other hand, Soybean is often used to improve the protein quality of cereal blends, due to its high levels of protein (40\%) and fat $(20 \%)$ content. Moreover, soybean is rich in lysine which deficient in most cereals; however, lack in sulfur containing amino acids as in legumes (Obatolu, 2002).

Low cost extrusion cooking is a food processing technology that rapidly mixes and cooks the feed material at temperatures of over $100^{\circ} \mathrm{C}$ and dry the product in a relatively short time. This thermal process improves the nutritional quality of raw food material and eliminates vegetative microorganisms. This process can be used to produce product in large scale for the developing countries (Bangoura and Zhou, 2007). Yoghurt is a firm, creamy or liquid acidified milk product manufactured from pasteurized milk using thermophilic lactic acid bacteria (Lactobacillus bulgaricus and Streptococcus thermophilus). Yoghurt is popular worldwide due to its health benefits as a functional food in addition to its nutritional 
benefits. As the milk proteins, fat, and lactose components undergo partial hydrolysis during fermentation, yoghurt is an easily digested product of milk (Tamime and Robinson, 1999). In addition, yoghurt is a good solution for people with lactose intolerance. Therefore, incorporation of yoghurt into the children's diet is an added advantage. Though many infant formulas are available in the market, there is a problem whether those are fulfilling the child's nutritional requirement and are affordable for the low income families where the malnutrition occurs. Hence, this study was an exploratory work to formulate energy and nutritional rich composite blend, based on locally available cereals such as rice, and legumes such as soybean and mung bean by blending with yoghurt to produce a highly nutritious yoghurt-based weaning food to reduce the malnourishment among the Sri Lankan children. Therefore, the objective of the current study was to formulate a yoghurtbased weaning food for toddlers by blending rice, mung beans and soy beans which provide the recommended nutritional requirements for toddlers.

\section{MATERIALS AND METHODS}

Rice (Oryza sativa), green gram (Vigna radiata), soy bean (Glycine max), cocoa powder and full cream milk powder were purchased from the local market.

\section{Preparation of the raw materials}

Green gram were washed, soaked $(8 \mathrm{~h})$, dried (at $50{ }^{\circ} \mathrm{C}$ for $24 \mathrm{~h}$ ) and roasted under an open flame $\left(160{ }^{\circ} \mathrm{C}\right)$ until become golden brown, and partially milled using a Ferrell-Ross ${ }^{\circledR}$ roller mill (Ferrell-Ross Corp, Oklanoma city, Okla, USA). Rice were washed, dried in a dehydrator $\left(55^{\circ} \mathrm{C}\right.$ for $\left.1 \mathrm{~h}\right)$ and partially milled using a Ferrell-Ross ${ }^{\circledR}$ roller mill (Ferrell-Ross Corp, Oklanoma city, Okla, USA). Soybean grains were soaked $(8 \mathrm{~h})$, drained by placing on a nylon sieve $(1 \mathrm{~h})$, dried at $50{ }^{\circ} \mathrm{C}$ for $24 \mathrm{~h}$ and roasted under an open flame $\left(160^{\circ} \mathrm{C}\right)$ until become golden brown coloured. Then dehulled using a Bauer 148-2 de-huller (Bauer bros.co, USA) and partially milled using a Ferrell-Ross ${ }^{\circledR}$ roller mill (Ferrell-Ross Corp, Oklanoma city, Okla, USA).

\section{Preparation of Set Yoghurt}

Cow milk was obtained from Mawela farm, University of Peradeniya, Sri Lanka. Milk was standardized with cream in order to obtain a final fat content of $4 \%$. Standardized milk was heated to $60{ }^{\circ} \mathrm{C}$ and homogenized. Then sugar and gelatin were added and the mix was pasteurized $\left(95{ }^{\circ} \mathrm{C}\right.$ for $5 \mathrm{~min}$ ). Then the mix was cooled to $45^{\circ} \mathrm{C}$ and the starter culture containing Streptococcus thermophilus and Lactobacillus bulgaricus was added at the rate of $2 \%(\mathrm{w} / \mathrm{v})$. The mix was incubated in an ACP incubator (ACP Co Ltd, Japan) at 42$45^{\circ} \mathrm{C} 2 \mathrm{~h}$. Incubation was terminated at $\mathrm{pH} 4.6$ and stored under refrigerated conditions until use.

\section{Treatments and Formulation}

Trial and error method was used to formulate three weaning foods (WF1, WF2 and WF3) that fulfills the nutrient requirement of toddlers according to the WHO recommendations (WHO, 1998). A $100 \mathrm{~g}$ portion of each of these mixtures was formulated to provide $1 / 3$ of daily energy and carbohydrate requirement, $2 / 3$ of daily protein requirement and $1 / 4$ of daily fat requirement of a growing toddler. The ingredient ratios were estimated using nutrient and caloric values of each ingredient. After the flour and yoghurt ratios of three weaning foods have been determined, the next step was to calculate the amount of each ingredient which was used to formulate the flour mixture. Prepared mung bean, soy bean and rice were blended according to the relevant proportions as stated in the Table 01. Each blend was extruded separately using a co- rotating twin screw extruder (die size 0.25 inches) with a smooth barrel. The resulted extruded products were milled into flour using a Fitz ${ }^{\circledR}$ 832D 
Fitz mill (The Fitzpatrick Company ${ }^{\text {Russia) }}$ and sieved through a $0.3 \mathrm{~mm}$ sieve. Thereafter, $3 \%$ spray dried milk powder and $5 \%$ coco powder were added to each blend. Then the composite flour mixtures of each treatment were mixed with corresponding yoghurt volume as shown in the Table 01 in order to prepare three yoghurt-based weaning foods (WF1, WF2 and WF3) and compared with Cerelac which assigned into 4 treatments as $\mathrm{T} 1, \mathrm{~T} 2, \mathrm{~T} 3$ and T4, respectively. Cerelac was used as the reference weaning food since it has a higher acceptability and popularity among other infant baby foods.

\section{Nutritional Analysis}

The developed three weaning foods and the commercial weaning food were analyzed for chemical, physical, microbiological and sensory properties.

\section{Chemical analysis}

The moisture, dry matter, ash, crude protein, crude fat and crude fiber content of the four treatments were analyzed by proximate composition analysis as described in the AOAC protocols (1995).

\section{Determination of Physical Properties}

The water binding capacity and water solubility index were determined according to the methods previously described by Griffith et al., (1998). Energy conversion factors given by Bangoura and Zhou (2007) were used in calculating the caloric value of the nutrients.

\section{Evaluation of Shelf life}

Since this weaning food is expected to be marketed in two separate parts: one for yoghurt mixture and the other for grain mixture, however in the same container, the shelf life was determined separately for the flour mixture and yoghurt. Moisture content in the flour mixture was determined at 7 day intervals until 21 days of storage according to the method previously described by Amankwah et al., (2009); whereas, the $\mathrm{pH}$ and Titratable acidity were determined for the yoghurt 4 days interval during storage at $4{ }^{\circ} \mathrm{C}$ with two replicates for 28 days. Nine milliliters of the sample was taken into $100 \mathrm{ml}$ Erlen Mayer Flask and $1 \mathrm{ml}$ of $1 \%$ phenolphalein solution was added into it. Then the sample was titrated with $0.1 \mathrm{~N} \mathrm{NaOH}$ until a permanent pale pink color was observed and the burette reading (V) was recorded in order to determine the Titratable acidity (\%) according to the following formula.

\section{Titratable acidity $(\%)(w / v)=V / \mathbb{0}$}

pH was measured using the Hannah 211 electric pH meter ( Hannah Corp, Mauritius).

Microbiological Analysis

Table 01: Compositions of the Treatments used for the sensory evaluation

\begin{tabular}{lllll}
\hline Ingredients & $\mathrm{T} 1(\mathrm{~g})$ & $\mathrm{T} 2(\mathrm{~g})$ & $\mathrm{T} 3(\mathrm{~g})$ & $\mathrm{T} 4(\mathrm{~g})$ \\
\hline Brown Rice & 2 & 2 & 2 & $14.28 \mathrm{~g}$ weaning food pow- \\
Mung beans & 11 & 17 & 22 & $\begin{array}{l}\text { der with 85.71 ml liquid } \\
\text { milk* }\end{array}$ \\
Soy bean & 4 & 3 & 3 & \\
Dried milk powder & 3 & 3 & 3 & \\
Yoghurt & 80 & 75 & 70 & \\
\hline Total & 100 & 100 & 100 & 100 \\
\hline
\end{tabular}

*This ratio was taken according to the instructions given by the manufacturer as displayed on the package. 
The microbiological analysis was conducted separately for the grain mixture, yoghurt and for the freshly prepared gruel form mixed with yoghurt.

\section{Coliform count of yoghurt}

Test was done for the minus one dilution and without any dilution (direct). For the direct pouring point one milliliter from each sample was transferred into sterile petri-dish which was kept in a Heraeus T $5042 \mathrm{~K}$ drying oven (Tamson, Zoetermeer, Holland) for $2 \mathrm{~h}$. Point one milliliters $(0.1 \mathrm{~mL})$ from $10^{-1}$ dilution series was poured into another petri-dish for checking the coliform count for $10^{-1}$ dilution of the sample. Then $12 \mathrm{~mL}$ of Violet Red Bile (VRB) agar $48 \pm 1{ }^{\circ} \mathrm{C}$ was poured into each Petri -dish followed by mixing the content by rotating the closed Petri-dishes. The agar was then allowed to solidify at room temperature $\left(27^{\circ} \mathrm{C}\right)$. The plates were incubated in an inverted position aerobically at $30 \pm 1{ }^{\circ} \mathrm{C}$ for $24 \mathrm{~h}$ in a Fisher 322 incubator (Scientific Company, USA). The colonies were counted manually and the results were expressed as Coliforms Colony Forming Units (CFU) per gram. Colonies were identified as enumerate blue and red colonies associated with entrapped gas regardless of size or intensity of color (Ahima, 2011).

Coliform count and total viable count / standard plate count/aerobic plate count for Flour mixture

Coliform count in the flour mixture was determined according to the same procedure as described so far. Total viable plate count was determined for the dilution series from $10^{-1}$ to $10^{-6}$. Nevertheless, $10^{-1}$ dilution was made from $0.1 \mathrm{~g}$ of each sample dissolved in $0.9 \mathrm{~mL}$ of distilled water. Moreover, $10^{-2}$ dilution was made from dissolving $0.1 \mathrm{~mL}$ from $10^{-1}$ dilution in a $0.9 \mathrm{~mL}$ of distilled water and other dilution levels were made according to the same procedure. Then 0.1 $\mathrm{mL}$ from each dilution were poured into Petri- dish containing $12 \mathrm{~mL}$ of plate count agar at $48 \pm 1{ }^{\circ} \mathrm{C}$ followed by mixing the content by rotating the closed Petri-dishes. The agar was then allowed to solidify at room temperature $\left(27^{\circ} \mathrm{C}\right)$. The plates were incubated in an inverted position at $37^{\circ} \mathrm{C}$ for $48 \mathrm{~h}$ in a Fisher 322 incubator (Scientific Company, USA). The colonies were counted manually and the results were expressed as the number of Colony Forming Units (CFU) per gram.

\section{Statistical analysis}

Statistical analysis was carried out using Complete Randomized Design (CRD) with SAS version 9.0, and all determinations were done in triplicate. Least significant difference (LSD) mean separation procedure of the SAS computer package was used to obtain the mean separation of the results obtained. Any significant differences were determined at $P<$ 0.05 level.

\section{RESULTS AND DISCUSSION}

\section{Nutritional composition of the weaning foods}

The proximate composition of the three evaluated yoghurt-based weaning foods (T1, T2 and T3) and commercial weaning food (T4) is stated in the Table 02 which was used to determine overall nutritional content of the formulated diets.

\section{Protein content}

Mung bean and soybean were used as the main plant protein source while yoghurt was used as the main animal protein source. The protein content of formulated weaning foods were higher than $(P<0.05)$ the levels in commercial weaning food. These results were similar to those reported by Bangora and Zhou (2007). The protein content of WF1, WF2 and WF3 were approximately five times higher than that of the WF4 (commercial product) where the mean values ranged from 16.28 to 03.77 (\% DM). The recommended amount of the commercial weaning food also provides less 
protein content than the prepared formulations (WF1, WF2, and WF3). This higher protein content could be due to the processing techniques used to prepare the formulated weaning foods such as roasting which might helps breakdown of lipocytes to release fat and protein (Wikramanayake, 1996). Roasting improved sensory qualities and aided in inactivation of destructive enzymes, which improves the storage and nutritional quality of the product and reduce trypsin inhibitor activity when seed temperatures reached 90-100 ${ }^{\circ} \mathrm{C}$ where the lipoxygenase activity loss at temperatures of $75-80{ }^{\circ} \mathrm{C}$ (Griffith et al., 1998). According to FAO/WHO (1982) a minimum protein content of $15 \%$ is required for maximum complementation of amino acids in foods and for growth. Thus all these three formulations were satisfied the protein demand of 1-3 year old children. According to Wickramanayake (1996) the high lysine content of legumes improve the nutritional quality of cereals by complementing the limiting amino acids. Sulphur containing amino acids such as methionine are limiting in legumes and relatively high in cereals whereas lysine is limiting in cereals and high in legumes.

\section{Moisture Content}

The moisture content of formulated weaning foods (gruel form) were significantly $(P<$ $0.05)$ lower than the levels in commercial weaning food. The moisture content values were ranged from 56.42 to $77.42 \%$ where the commercial product has shown the highest mean moisture content. Perhaps this could be due to its high water binding capacity. The moisture content of different treatments is displayed in the Table 03 .

Nielsen (1994) has reported that moisture

Table 02: Proximate composition and energy content of supplementary diets (Dry weight basis) $(\mathrm{WF}=$ Weaning Food $)$

\begin{tabular}{lllll}
\hline Nutrient (\%) & \multicolumn{1}{c}{ WF1 } & \multicolumn{1}{c}{ WF2 } & \multicolumn{1}{c}{ WF3 } & WF4 \\
\hline Crude protein & $15.22 \pm 0.32^{\mathrm{b}}$ & $16.28 \pm 0.37^{\mathrm{a}}$ & $16.19 \pm 0.28^{\mathrm{a}}$ & $03.77 \pm 0.14^{\mathrm{c}}$ \\
Moisture & $56.42 \pm 1.00^{\mathrm{b}}$ & $53.53 \pm 1.16^{\mathrm{c}}$ & $50.75 \pm 0.35^{\mathrm{d}}$ & $77.42 \pm 0.46^{\mathrm{a}}$ \\
Dry matter & $42.53 \pm 0.04^{\mathrm{b}}$ & $42.53 \pm 0.04^{\mathrm{b}}$ & $50.18 \pm 0.05^{\mathrm{a}}$ & $24.57 \pm 2.28^{\mathrm{c}}$ \\
Crude fiber & $0.71 \pm 0.19^{\mathrm{c}}$ & $0.93 \pm 0.10^{\mathrm{a}}$ & $0.81 \pm 0.12^{\mathrm{b}}$ & $0.54 \pm 0.02^{\mathrm{d}}$ \\
Crude fat & $12.43 \pm 0.37^{\mathrm{a}}$ & $12.38 \pm 0.31^{\mathrm{a}}$ & $12.38 \pm 0.31^{\mathrm{a}}$ & $02.70 \pm 0.31^{\mathrm{b}}$ \\
Carbohydrates & $69.07 \pm 0.20^{\mathrm{a}}$ & $68.55 \pm 0.30^{\mathrm{b}}$ & $68.10 \pm 0.35^{\mathrm{b}}$ & $92.25 \pm 0.40^{\mathrm{a}}$ \\
Ash & $1.70 \pm 0.05^{\mathrm{a}}$ & $1.69 \pm 0.12^{\mathrm{a}}$ & $1.66 \pm 0.30^{\mathrm{a}}$ & $1.04 \pm 0.10^{\mathrm{b}}$ \\
Energy (kJ) & $1854.36 \pm 1.20^{\mathrm{a}}$ & $1845.08 \pm 0.41^{\mathrm{ab}}$ & $1835.99 \pm 0.61^{\mathrm{b}}$ & $1612.51 \pm 0.38^{\mathrm{c}}$ \\
\hline
\end{tabular}

Note: All values in the same column with different superscripts are significantly different at $(P<0.05)$

Table 03: Moisture content of the weaning food flour mixtures and yoghurt

\begin{tabular}{lc}
\hline Weaning Food & Moisture $\%$ \\
\hline Flour mixture of WF1 & $4.55^{\mathrm{b}}$ \\
Flour mixture of WF2 & $4.85^{\mathrm{b}}$ \\
Flour mixture of WF3 & $4.55^{\mathrm{b}}$ \\
Flour mixture of WF4 & $2.36^{\mathrm{c}}$ \\
Yoghurt & $69.51^{\mathrm{a}}$ \\
\hline
\end{tabular}

Note: All values in the same column with different superscripts are significantly different at $(P<0.05)$ 
content is used as a quality factor for prepared cereals which should have 3-8\% moisture. The moisture content of formulated weaning food flour mixtures were significantly $(P$ $<0.05$ ) higher than the levels in commercial weaning food. But they were within the acceptable range with low mean moisture contents which fulfills the Protein Advisory Group Recommendations (1972). Moisture content should be between 5 to $10 \%$ and they are required for convenient packaging and transport of products (Oduro et al., 2007). Therefore, moisture contents of the evaluated formulated weaning foods were within those critical values.

\section{Dry Matter Content}

The dry matter content of formulated weaning foods (gruel form) were significantly ( $P$ $<0.05)$ higher than the levels in commercial weaning food. The moisture content values were ranged from 24.57 to $50.18 \%$ where the WF3 showed the highest mean moisture content. The dry matter content higher means overall nutritional content is also high.

\section{Crude Fat Content}

The crude fat content of formulated weaning foods were significantly $(P<0.05)$ higher than the levels in commercial weaning food. The crude fat content of formulated weaning foods was able to supply $1 / 4$ of the daily fat requirement of a 1-3 year old toddler whereas recommended amount of commercial food supplies only one $1 / 8$ of the fat requirement. The fat content of a food sample can affect its shelf stability. This is because fat can undergo oxidative deterioration, which leads to rancidification and spoilage. Hence a food sample with high fat content is more liable to spoilage than one with a lower fat content (Amankwah et al., 2009). Protein Advisory group (1972) recommends fat content of a weaning food should be not more than $10 \%$ due to oxidative deterioration. But in the formulated diets as yoghurt and flour mixture keep separately total fat content of $12 \%$ will not affect for its shelf life. In the current study, soybean and yoghurt were used as the main fat suppliers. Soy bean oil agree with the recommendations of (FAO/WHO, 1998) that vegetable oils can be included in foods meant for infants and children, which will not only increase the energy density, but also be a carrier for fat soluble vitamins and provide essential fatty acids. Soybean and cereals contain unsaturated fats (Wikramanayake, 1996) which does not increase the cholesterol in the blood hence can be recommended for children.

\section{Ash Content}

WF1 gave the highest mean value for the ash $\%$. The ash content of formulated weaning foods were significantly $(P<0.05)$ higher than the levels in commercial weaning food. But ash contents were the same $(P>0.05)$ between the formulated diets. The ash content of the products indicates the mineral content of the products. Acceptable ash content of weaning foods which given by the Protein Advisory Group recommendations (1972) should not exceed $5 \%$. Formulated foods studied in the current study were within this limit as well.

\section{Crude Fiber Content}

The lowest mean value for crude fiber content was observed in WF4. The crude fiber content of formulated weaning foods were significantly $(P<0.05)$ higher than the levels in commercial weaning food. Acceptable fiber content of weaning foods should not exceed 5\% according to the Protein Advisory Group Recommendations (1972) since when the fiber content is high it decreases the digestibility of the particular food. The crude fuber content of the evaluated formulated foods were within this acceptable range. The dietary fiber fractions of all weaning foods were comparatively low due to the incorporation of de-hulled legumes (Ghasemzadeh and Ghavide, 2011). 


\section{Analysis of carbohydrate content}

The carbohydrate content of formulated weaning foods were significantly $(P<0.05)$ lower than the levels in commercial weaning food. The commercial product has shown the highest mean $\mathrm{CHO}$ content and this is because of its lower crude protein and crude fat contents. All these three formulated weaning foods were able to supply one third of daily carbohydrate requirement of a 1-3 years old toddler. In this study brown rice was used as the main carbohydrate supplier which helped to maintain the carbohydrate content over $65 \%$ as the recommendations made by Protein Advisory Group (1972).

\section{Physical Property Analysis}

\section{Caloric Content}

Table 04 shows the caloric values of each nutrient in different weaning foods which evaluated in the current research study. Calories in a diet is provided by protein, fat and carbohydrates (Wikramanayake, 1996). The calorie content of formulated weaning foods were significantly $(P<0.05)$ higher than the levels in commercial weaning food. These results were similar to those reported by (Bangoura and Zhou, 2007). The values were ranged from 385.77 to 443.63 . Weaning foods were provided protein caloric content ranges from 16.58 to 68.37 respectively and provided $4.19 \%$ to $26.69 \%$ of energy content.
The fat caloric content of formulations was ranges from 26.8467 to 118.5133 and representing $6.92 \%$ to $26.69 \%$ energy content. Carbohydrate caloric content was determined as 257.3267 to 343.6300 and provided $58.31 \%$ to $88.87 \%$ of energy content. The carbohydrate caloric a content of commercial weaning food was slightly higher than the Protein Advisory Group (1972) values of 50$60 \%$ due to higher carbohydrate content and formulated foods were within the acceptable range. Protein caloric content of formulated diets were in acceptable range of 10\%-20\% and also in the acceptable range of fat caloric content which is below $30 \%$ recommended by Protein Advisory Group (1972).This indicates that formulated weaning foods were supplied one third of needed energy per day of a 1-3 years old toddler.

\section{Water Binding Capacity (WBC)}

The WBC of formulated weaning foods were significantly $(P<0.05)$ lower than the levels in commercial weaning food (Table 05). The high fat, high protein, low carbohydrate content of weaning food corresponds to the reduced WBC observed (Griffith et al, 1998). When starch content is high as in commercial weaning food then the water binding capacity also high because starch absorbs more water. Lower absorption capacity is desirable for making thinner gruels (Ghasemzadeh and Ghavide, 2011).

Table 04: Caloric values supply by each nutrient as ingredient in different weaning foods

\begin{tabular}{lllll}
\hline WF & Caloric value $(\mathrm{kcal})$ & $\begin{array}{l}\text { Protein caloric } \\
\text { content }(\mathrm{kcal})\end{array}$ & $\begin{array}{l}\text { Fat caloric } \\
\text { content }(\mathrm{kcal})\end{array}$ & CHO caloric $(\mathrm{kcal})$ \\
\hline WF1 & $443.63^{\mathrm{a}}\left(1854.36^{\mathrm{a}} \mathrm{kj}\right)$ & $65.65^{\mathrm{b}}$ & $118.51^{\mathrm{a}}$ & $259.64^{\mathrm{b}}$ \\
WF2 & $441.41^{\mathrm{ab}}\left(1845.08^{\mathrm{ab}} \mathrm{kj}\right)$ & $65.65^{\mathrm{b}}$ & $117.00^{\mathrm{a}}$ & $257.33^{\mathrm{c}}$ \\
WF3 & $439.23^{\mathrm{b}}\left(1835.99^{\mathrm{b}} \mathrm{kj}\right)$ & $68.37^{\mathrm{a}}$ & $113.12^{\mathrm{b}}$ & $257.86^{\mathrm{c}}$ \\
WF4 & $385.77^{\mathrm{c}}\left(1612.51^{\mathrm{c}} \mathrm{kj}\right)$ & $16.58^{\mathrm{c}}$ & $026.85^{\mathrm{c}}$ & $34363^{\mathrm{a}}$ \\
\hline
\end{tabular}

Note: All values in the same column with different superscripts are significantly different at $(P<0.05)$ 
Table 05: Water Binding Capacity (WBC) and Water Solubility Index (WSI) of the weaning foods

\begin{tabular}{lll}
\hline WF & WBC $(\mathrm{ml} / \mathrm{g})$ & WSI \\
\hline WF1 & $3.06 \pm 0.04^{\mathrm{a}}$ & $17.24 \pm 0.23^{\mathrm{c}}$ \\
WF2 & $1.67 \pm 0.06^{\mathrm{c}}$ & $30.28 \pm 0.06^{\mathrm{a}}$ \\
WF3 & $2.49 \pm 0.05^{\mathrm{b}}$ & $27.55 \pm 0.05^{\mathrm{b}}$ \\
WF4 & $3.28 \pm 0.23^{\mathrm{a}}$ & $12.46 \pm 0.04^{\mathrm{d}}$ \\
\hline
\end{tabular}

Note: All values in the same column with different superscripts are significantly different at $(P<0.05)$ Superscripts with the same letter are not significantly different

\section{Water Solubility Index (WSI)}

The WSI of formulated weaning foods were significantly $(P<0.05)$ higher than the levels in commercial weaning food (Table 05). WAI and WSI showed an inverse relationship ( $r$ $=-0.916)$. When water solubility is high it will make a fine paste and improve the mouth feel. Sugar and milk powder can be added to increase the WSI. The extruded products usually increase the water solubility because, cooking increase the susceptibility of grain starch to glucoamylase hydrolysis indicating that starch was gelatinized during processing (Griffit et al, 1998).

\section{Microbiological analysis}

Microbiological analysis was conducted for the gruel prepared by blending yoghurt and flour mixture and for the flour mixture and yoghurt separately to determine their wholesome for consumption. According to Sri Lankan Standards (SLS) (1989) for the yoghurt, acceptable coli form count is $<1 \mathrm{CFU} / \mathrm{g}$. Hence
Coliform counts of both flour mixtures and yoghurt were in acceptable range (Table 06). According to the recommendations of UK Food Protection Agency and Food Standards Australia New Zealand (FSANZ) acceptable Total Plate Count (TPC) for cereal flour mixtures is $<10^{7} \mathrm{CFU} / \mathrm{g}$ and coliform count is $<3 \mathrm{CFU} / \mathrm{g}$ and formulated weaning foods were in that acceptable range. The spoilage of many foods may be imminent when the total viable count reaches 10-100 million per gram of product.

Moreover, the TPC and coliform counts of each treatment in gruel form are displayed in the Table 07. According to recommendations of UK Food Protection Agency and Food Standards Australia New Zealand (FSANZ) acceptable Total Plate Count (TPC) for ready to eat food items is $<10^{5} \mathrm{CFU} / \mathrm{g}$ and coliform count is $<3 \mathrm{CFU} / \mathrm{g}$. Formulated weaning foods were in that acceptable range and wholesome to consume.

Table 06: Microbiological analysis for the weaning food flour mixtures and yoghurt separately

\begin{tabular}{lll}
\hline $\begin{array}{lll}\text { Component of weaning } \\
\text { food }\end{array}$ & TPC $(\mathrm{CFU} / \mathrm{g}) \times\left(10^{6}\right)$ & Coliform count $(\mathrm{CFU} / \mathrm{g})$ \\
\hline WF1 flour mixture & 2.80 & 0 \\
WF2 flour mixture & 2.75 & 0 \\
WF3 flour mixture & 3.20 & 0 \\
WF4 flour mixture & 2.45 & 0 \\
Note: $N D$ & ND & 0 \\
\hline Yoghurt & &
\end{tabular}


Table 07: Microbiological analysis of weaning foods in gruel form

\begin{tabular}{lll}
\hline $\begin{array}{l}\text { Weaning food in gruel form(fresh } \\
\text { sample) }\end{array}$ & TPC $(\mathrm{CFU} / \mathrm{g}) \times\left(10^{4}\right)$ & Coliform count $(\mathrm{CFU} / \mathrm{g})$ \\
\hline WF1 & 5.94 & 0 \\
WF2 & 5.62 & 0 \\
WF3 & 6.34 & 0 \\
WF4 & 5.79 & 0 \\
\hline
\end{tabular}

Note: WF= Weaning Food

\section{Shelf Life Determination}

Variation in Moisture Content during the Storage

The diets were packaged in triple laminated Aluminum foil. After 21 days with 7 days intervals, moisture content of the diets were determined to find out if the packaging material could serve as a good barrier between diets and environment. Figure 01 illustrates the variation in moisture content over the experimental period with regard to the treatments.

The moisture content in WF1 increased from $4.85 \%$ to $5.82 \%$ for 21 days. In WF2 it was increased from $4.96 \%$ to $6.78 \%$ and in WF3 increased from $4.8 \%$ to 5.87 and in FW4 from $2.42 \%$ to $\mathrm{FW} 3.89 \%$. The change in moisture content may be due to the ineffective sealing of the packaged products; hence air movement and moisture were increased. The resulting moisture contents of all formulations were fallen within the moisture content of $3-8 \%$ recommended by the Protein Advisory Group. Moisture contents were same $(P>0.05)$ before and after 21 days and that implied the formulations were stable even after 21 days of formulation. The products will have longer shelf life if stored at low temperatures, due to slow air movement and low moisture diffusion coefficient (Amankwah et al., 2009).

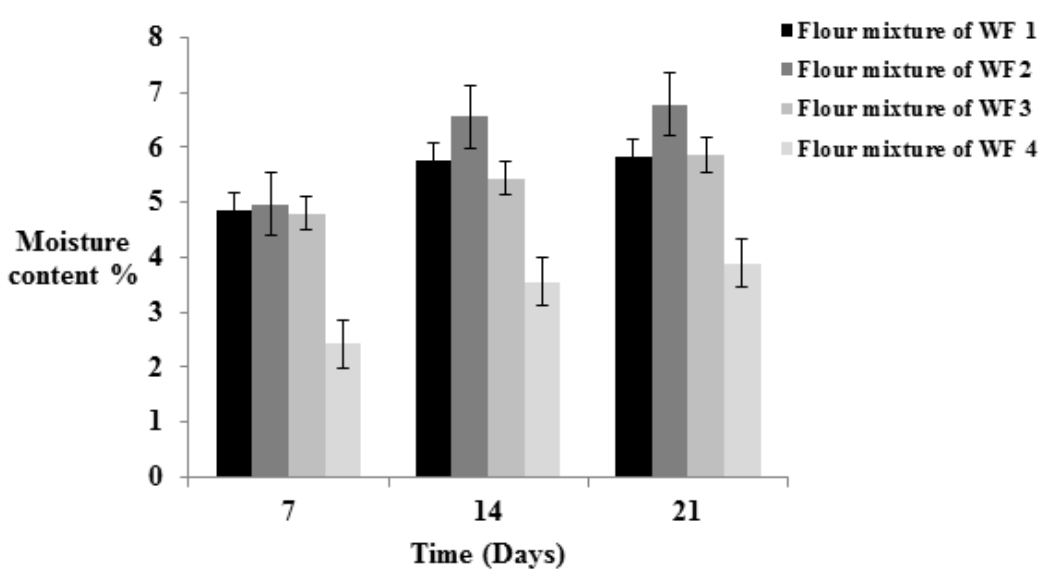

Figure 01: Change in the moisture content of different treatment with time over the experimental period 


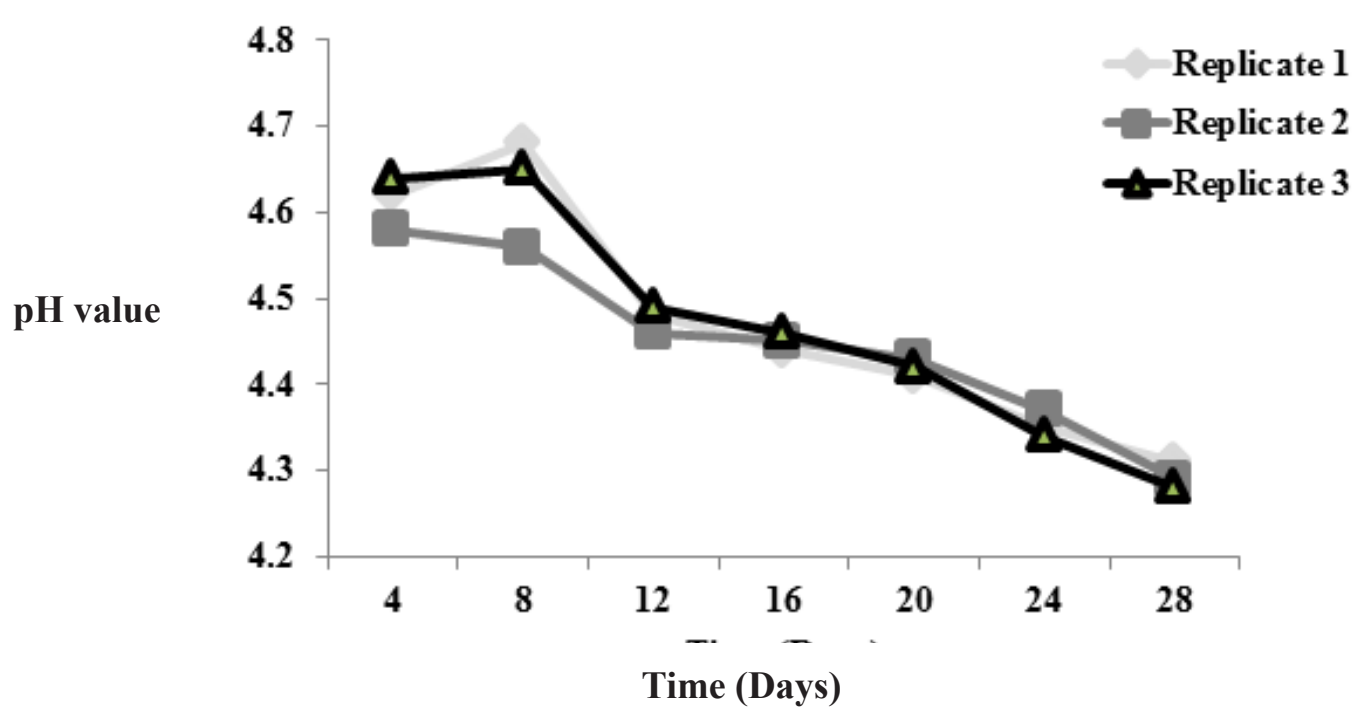

Figure 02: Variation in the pH value of yoghurt over the experimental period

Variation $p H$ of yoghurt during the Refrigerated Storage

The variation in $\mathrm{pH}$ of the yoghurt is illustrated in the Figure 02 which was measured at 4 days interval over 28 days. $\mathrm{pH}$ value was declined throughout the storage period of the yoghurt. $\mathrm{pH}$ value of the replicate one varies from 4.62 to $4.31,4.58$ to 4.29 and 4.64 to 4.28 in the replicate 1,2 and 3 , respectively. On the $20^{\text {th }}$ day, sour taste and unpleasant odor were observed and therefore, yoghurt was not suitable for the consumption. Hence shelf life of the yoghurt was determined as 16 days.
Variation in Titratable Acidity of yoghurt during the Refrigerated Storage

The variation in the Titratable acidity of the yoghurt (3 replicates) which was measured at 4 days interval over 28 days has been illustrated in the Figure 03. Titratable acidity was increased throughout the storage period of the yoghurt. The highest change was observed in the replicate 1 . These values were within the recommended range of titratable acidity of yoghurt which is $0.8-1.25 \%$ according to the SLS (1989). Therefore, the shelf life of the yoghurt was confirmed as 16 days by considering the $\mathrm{pH}$ value also.

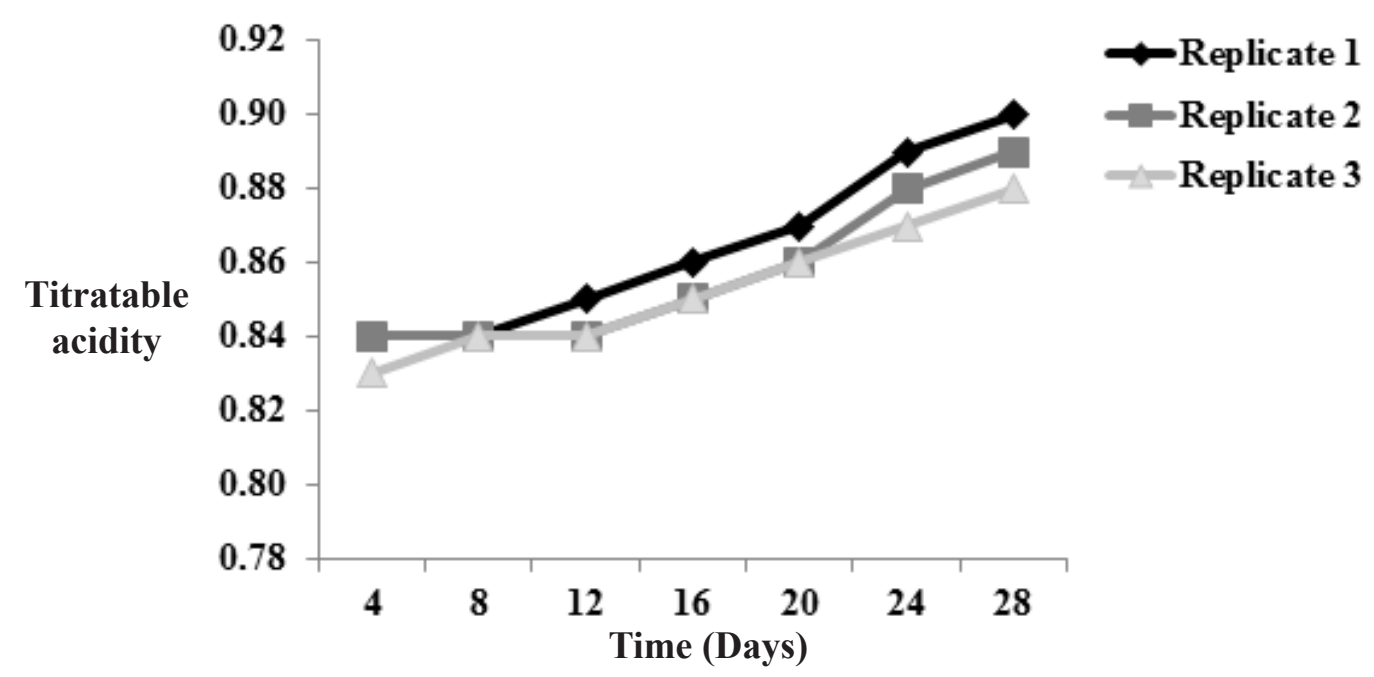

Figure 03: Variation in the Titratable acidity of the yoghurt over the experimental time 


\section{CONCLUSIONS}

This study suggests that formulation of weaning food from yoghurt, rice, soybean and mung bean can be achieved successfully while fulfilling the nutritional requirements of toddlers. According to the chemical and physical property analyses, formulated WF2 can be selected as the best one. This formulated weaning food can be introduced as an alternative weaning food for Sri Lankan market especially for the low-income families living in rural areas. The yoghurt and grain flour had a shelf life of 16 and 21 days, respectively which suggesting the fact that it can be stored under refrigerated conditions $\left(4{ }^{\circ} \mathrm{C}\right)$ for 14 days which is the general shelf life assigned to retail yoghurt. In general, formulate weaning foods supply nutritional requirement of a one to three years old toddler than commercial weaning food: Cerelac.

\section{SUGGESTIONS}

Extrusion processing can be a practical technique which can be used to process grains into precooked, dried flours with acceptable physicochemical, nutritional and storage characteristics to produce weaning foods in a large scale but at a low cost. This study revealed that ready to eat complementary food products formulated from locally available food commodities can meet the nutritional needs of toddlers. Finally this is a practical local food based approach aimed at mitigating the problem of malnutrition among infants and children in developing countries. Further work can be done on the fortification of the weaning food with vitamin and minerals. Digestibility and bio availability of the macronutrients in these local diets need further investigation. Inclusion of probiotics and determine their survival upon storage. A sensory evaluation will be done in the next step in order to find the best formulation according to the sensory properties.

\section{ACKNOWLEDMENT}

The great assistant provided by the technical staff of Food Research Unit, HORDI, and Dairy Science and Technology Laboratory, Animal Nutrition Laboratory and Food Science Laboratory of the Faculty of Agriculture, University of Peradeniya are highly acknowledged for their commitment to make this research study a success.

\section{REFERENCES}

Ahima, J. K. (2011). Formulation of weaning food using composite of maize groundnut and soybean and assessing its nutritional effect using animal model (Doctoral dissertation).

Amankwah, E. A., Barimah, J., Nuamah, A. K. M., Oldham, J. H., Nnaji, C. O. and Knust, P. (2009). Formulation of weaning food from fermented maize, rice, soybean and fishmeal. Pakistan Journal of Nutrition, 8(11), 1747-1752.

AOAC. (1995).Official Methods of Analysis of AOAC International, 16 ${ }^{\text {th }}$ ed: Association of Official Analytical Chemist, Maryland, USA.

Australia New Zealand Food Standards Code - Standard 1.6.1 - Microbiological Limits for Food. (2011), http://www.comlaw. gov.au/Details /F2011C00352, 24.12.2012.

Bangoura, M. L., and Zhou, H. (2007). Formulation and Nutritional Quality of Extruded Weaning Food Supplemented with Whole Egg Powder. American Journal of Food Technology, 2, 477-489. 
Department of Census and Statistics. (2009). Sri Lanka Demographic and Health Survey 200607. Ministry of Healthcare and Nutrition, Colombo, Sri Lanka.

Egounlety, M. (2002). Production of legume-fortified weaning foods. Food research international, $35(2), 233-237$.

FAO/WHO. (1982). Codex standard for foods for special dietary uses including foods for infants and children and related Code of Hygienic Practice. 1st ed: Codex Alimentarius, Rome, Italy.

Food and Agriculture Organization of the United Nations (FAO). (2012). The state of food insecurity in the world. FAO, Viale delle Terme di Caracalla, 00153 Rome, Italy.

Ghasemzadeh, R. and Ghavidel, R. A. (2011). Processing and Assesment of Quality Charactristic of Cereals-legumes Composite Weaning foods. 2011 International Cinference on Bioscience, Biochemistry and Bioinformatics, Singapore (Vol. 5). IACSIT Press, Singapore.

Griffith, L. D., Castell-Perez, M. E., and Griffith, M. E. (1998). Effects of blend and processing method on the nutritional quality of weaning foods made from select cereals and legumes. Cereal chemistry, 75(1), 105-112.

Harper, J. M., and Jansen, G. R. (1985). Production of nutritious precooked foods in developing countries by low-cost extrusion technology. Food Reviews International, 1(1), 27-97.

Nielsen, S. S. (1994). Introduction to the chemical analysis of foods. Boston: Jones and Bartlett.

Obatolu, V. A. (2002). Nutrient and sensory qualities of extruded malted or unmalted millet/ soybean mixture. Food chemistry, 76(2), 129-133.

Oduro, I., Ellis, W., Sulemana, A., and Oti-Boateng, P. (2007). Breakfast meal from breadfruit and soybean composite. Discovery and Innovation, 19, 238-242.

Protein Advisory Group. (1972). Guidelines Of Protein Rich Mixture For Use In Weaning Foods. Protein Advisory Group. New York.

Sanni, A. I., Onilude, A. A., and Ibidapo, O. T. (1999). Biochemical composition of infant weaning food fabricated from fermented blends of cereal and soybean. Food chemistry, 65(1), 35-39.

SLS. (1989).SLS standards for yoghurt 735:1989. Sri Lanka Standards Institute, Colombo.

Suite. (2007). Weaning Foods: Characteristics, Guidelines and the Role of Soy foods. World Initiative for Soy in Human Health: St. Louis, USA.

Tamime, A. Y. and Robinson, R. K. (1999). Yoghurt: science and technology. Woodhead Publishing.

UK Food Standards Agency, http://www.food.gov.uk/enforcement/regulation/\#.UTcx49b-FbE, 23.12.2012. 
Vijayalakshmi, P., Amirthaveni, S., Devadas, R. P., Weinberger, K., Tsou, S. C. S., and Shanmugasundaram, S. (2003). Enhanced bioavailability of iron from mungbeans and its effects on health of schoolchildren. Shanhua (Taiwan): AVRDC.

WHO. (1998). Preparation and Use of Food-based Dietary Guidelines. Report of a joint FAO. WHO Consultation, Nicosia, Cyprus, 1995WHO, Geneva.

WHO. (2008). Worldwide prevalence of anaemia 1993-2005, WHO Press, World Health Organization, 20 Avenue Appia, 1211, Geneva 27, Switzerland.

WHO. (2013). Micronutrient Deficiencies, http://www.who.int/nutrition/topics/ida/ en/index. html, 05.03.2013.

Wikramanayake, T. W. (1996). Food and Nutrition: Hector Kobbekaduwa Agrarian Research and Training Institute: Colombo 07, Sri Lanka. 